\title{
BIOSYSTEMATIC STUDIES ON SPERGULARIA MEDIA AND S. MARINA IN THE NETHERLANDS III. THE VARIABILITY OF S. MEDIA AND S. MARINA IN RELATION TO THE ENVIRON- MENT*
}

\section{A. A. STERK}

Hugo de Vries-laboratorium, Universiteit van Amsterdam

\section{SUMMARY}

In this third report of this series concerning biosystematic studies of the Dutch halophilous species of Spergularia, the relation between the variation and the environment is discussed. In the case of S.media, a correlation between the occurrence of populations with a high representation of plants with unwinged and subalate seeds and the degree of extremity of the abiotic factors prevailing in the habitat seems to be manifest. In some cases overgrazing by sheep or cattle also results in a relatively high representation of such plants in the population, even if the abiotic factors are favourable. The possible causes of a selective advantage of winged seeds over exalate seeds in certain types of habitats (and vice versa) are discussed. The predominantly autogamous S. marina occurs in populations consisting of plants with unwinged seeds. However, one population was found containing plants with winged seeds; the possible ecological causes of this phenomenon are mentioned.

\section{INTRODUCTION}

One of the principal goals of the present investigation was to acquire a better understanding of the variability of the population complexes of $S$. media and of $S$. marina by correlating it with the environmental factors.

Synecological studies (BraUn-BlanQueT, 1964) have shown that there is a close connection between the floral composition of a stand of vegetation and its environment. A change in environmental factors, generally speaking, results in an alteration of both the floristic and the structural composition of the stand. The starting-point for the investigation of the possible correlation between variation and environment is, accordingly, the composition of the stands, but this is by no means sufficient. It was deemed necessary also to study populations by sampling along important environmental gradients, including gradients in the composition of the soil, as they occur in the natural habitats of the two species in the estuarial regions of the northern and south-western parts of the Netherlands.

During the investigation, those historical and incidental factors always had to be taken into account which render the causal relation between variability and environment not necessarily, and certainly not invariably, of a purely adaptive nature.

* Published with financial aid from the Brummundfonds of The Royal Botanical Society of the Netherlands. 
The nomenclature used here for all taxa (except $S$. media and $S$. marina) is adopted from Heukels-VAN OOSTSTROOM (1962).

\section{VARIABILITY AND ENVIRONMENT}

\subsection{S. media}

\subsubsection{Its representation in stands of vegetation}

The ecological studies were considerably facilitated by the circumstance that the Dutch halophilous vegetation types have been extensively investigated. For surveys of the relevant publications the reader is referred to WESTHOFF (1947) and to BEEFTINK (1965). The analytical methods employed were those of the France-Swiss School (Ellenberg 1956; Braun-BlanQueT 1964) and these methods were also used during the present investigation for the description of the vegetation types concerned, which were classified according to the system proposed by BeEFTINK (1965).

S. media appears to be a differentiating species of the Glauceto-Puccinellietalia, which order includes the alliances Puccinellion maritimae and Armerion maritimae (BEEFTINK 1965; see also STERK 1968). Table 1 shows the degree of presence and the abundance-dominance assessments of $S$. media in the associations of these two alliances.

Table 1. The occurrence of S.media in the Puccinellion maritimae and the Armerion maritimae expressed in presence and abundance-dominance according to BRAUN-BLANQUET. After data from BEEFTINK 1965.

\begin{tabular}{ccccc}
\hline & Number of records & Presence & $\begin{array}{c}\text { Abundance- } \\
\text { Dominance }\end{array}$ \\
\hline $\begin{array}{c}\text { Puccinellion } \\
\text { maritimae }\end{array}$ & $\begin{array}{c}\text { Puccinellietum } \\
\text { maritimae } \\
\text { Halimionetum } \\
\text { portulacoidis }\end{array}$ & 168 & 75 & +-2 \\
$\begin{array}{c}\text { Armerion } \\
\text { maritimae }\end{array}$ & $\begin{array}{c}\text { Artemisietum } \\
\text { maritimae }\end{array}$ & 110 & 39 & +-2 \\
$\begin{array}{c}\text { Juncetum } \\
\text { gerardii } \\
\text { Junceto-Caricetum } \\
\text { extensae } \\
\text { Scirpetum rufi }\end{array}$ & 70 & 68 & 22 & +-2 \\
& 1 & - & +-1
\end{tabular}

It appears that this species exhibits the highest presence and abundance/ dominance in the Puccinellietum maritimae and the Artemisietum maritimae, both associations of the most saline sites. Striking is the lower degree of representation in the Halimionetum as compared to the other two associations. The explanation of this phenomenon is to be sought in the high sociability of Halimione portulacoides, so that it ousts out other species by spatial competition when it attains optimal development. In all the localities studied it was 
BIOSYSTEMATIC STUDIES ON SPERGULARIA III.

always found that in those sites included in the investigation which show a welldeveloped zonation including a Halimionetum, the optimum of development of $S$. media never lies within this community but either in the adjacent Puccinellietum maritimae zone below it or in the higher Artemisietum maritimae zone. The phytosociological analysis showed, furthermore, that the zone of optimal development of $S$. media is not always found at the same level in the zonation.

At the Kaloot (Zuid-Beveland), for instance, $S$. media is most abundant in the Puccinellietum in the low-lying depressions and not in the Artemisietum on the higher banks along-side the creeks. At the Spieringschor (Noord-Beveland) and the Savoyaardsplaat (Zeeuws-Vlaanderen), on the other hand, this species is optimally developed on the banks in the Artemisietum zone and does not occur in the lower-lying Puccinellietum. This singular "shift" of the optimum habitat is presumably a very complex phenomenon that can only be understood after extensive ecological studies. There are already some indications that moisture relations and aeration are important factors (STERK 1968). However, specific competition in the various associations most probably also has some bearing on the absence or the occurrence of $S$. media. Of considerable importance in connection with population studies are the sparse stands on stretches of flat sandy beaches in which $S$. media is often dominant. These pioneer communities constitute the initial successional stages in this habitat. In the zonation $S$. media occurs here below the Puccinellia maritima zone. By its occurrence at different levels in the zonation $S$. media exhibits to some extent an independent, individual behaviour in respect of the other species of the order GlaucetoPuccinellietalia. Such an independent behaviour of certain species was described as early as 1924 by Ramensky and independently again in 1926 by Gleason (see WhITTAKER 1962). Table 1 indicates that $S$. media does not occur with a presence of $100 \%$ in the vegetation recordings of the order, one of the principal reasons apparently being that its specific ecological amplitude is not so wide that the species can possibly occur in all associations of the order.

\subsubsection{Variation and environment in the northern part of the Netherlands}

For an extensive survey of the ecological data relating to the populations studied in the N. part of this country, the reader is referred to STERK 1968.

In the population samples from Terschelling, very divergent percentages of URW-capsules were recorded (STERK 1969a). The greatest difference was found between the sample from De Grie and that from the Boschplaat near no. 26 beach marker-pole N. of the dunes (see fig. 1). In the former no URW-capsules were recorded, whereas in the latter $30 \%$ URW-capsules were counted. The differences in variation can be correlated with differences in the respective habitats. De Grie is a clayey salting which has supported a dense stand of vegetation for centuries, so that here the environmental factors are comparatively stable and do not show such an extreme fluctuation as the environmental factors in the other site do. Under these conditions BVW-plants predominate and URW-plants are absent (see photo I). The situation at the Boschplaat site, in the beach plain seawards of the dunes especially towards the eastern end, is 
A. A. STERK

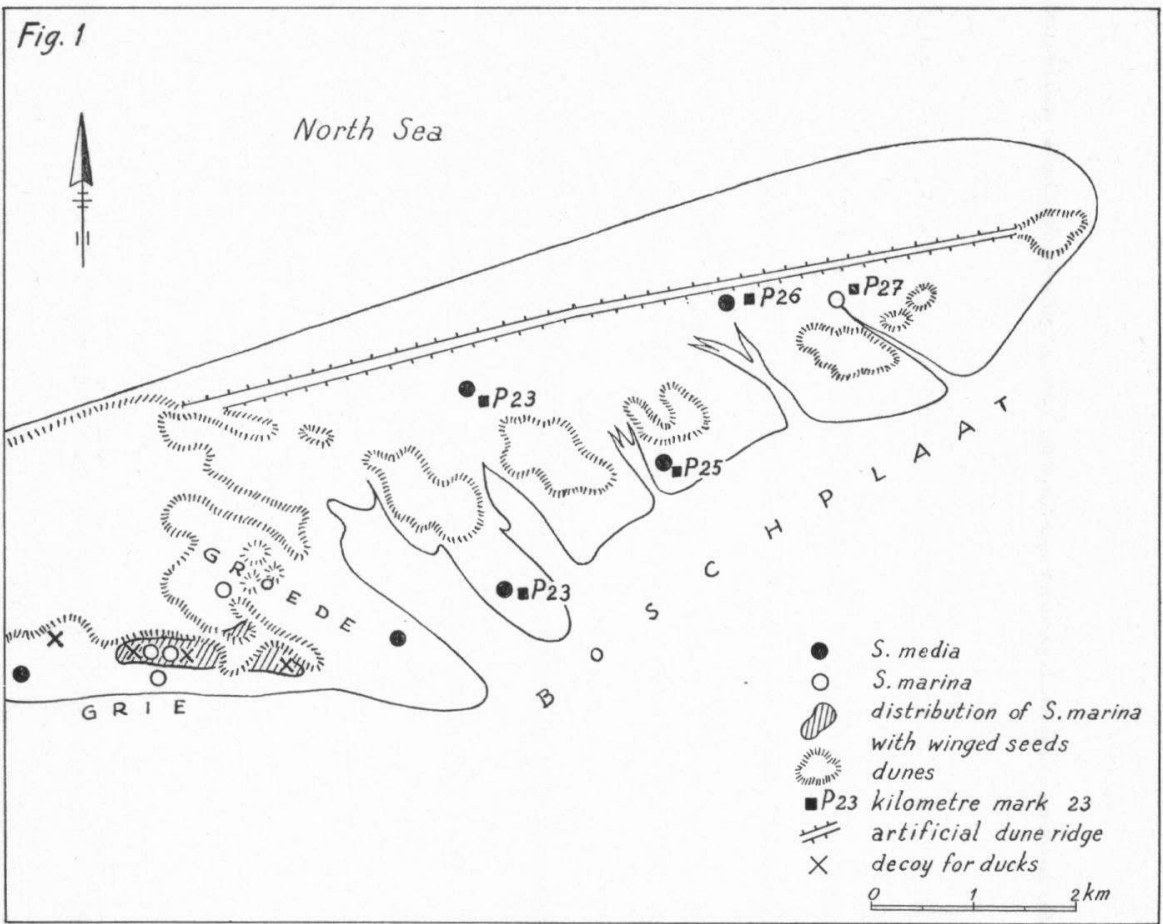

Fig. 1. Map of East-Terschelling showing the localities of the investigated populations.

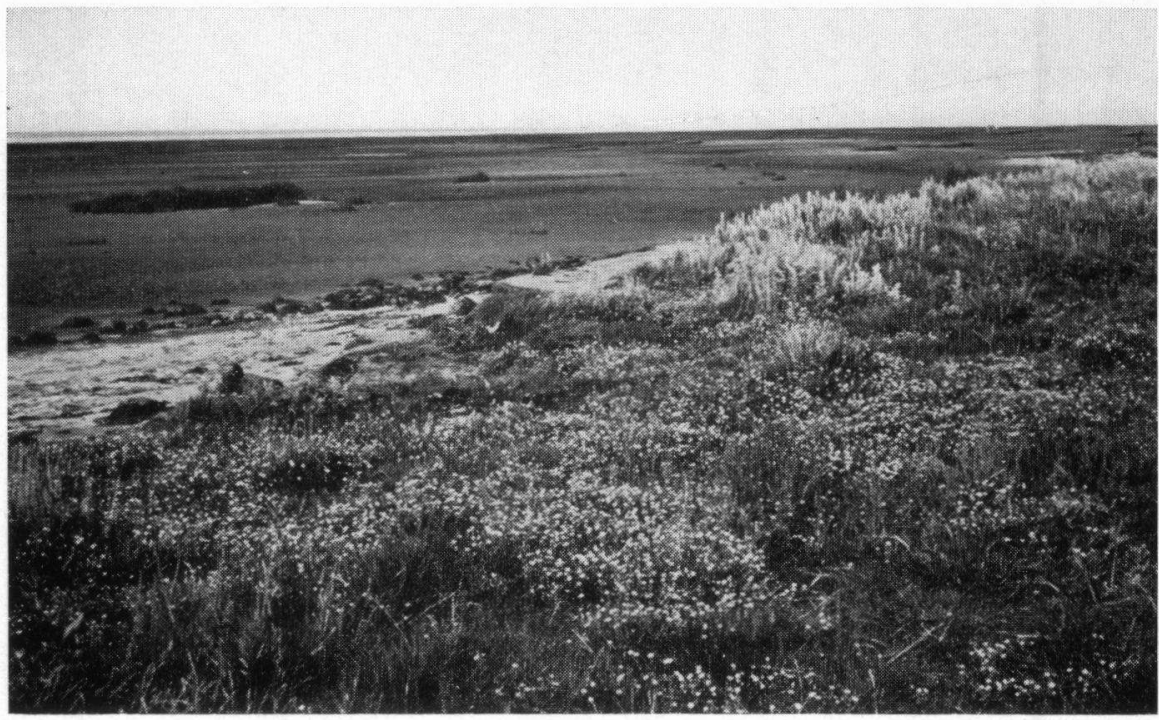

Photo 1.View of the habitat of S.media of "De Grie" (Terschelling). The population grows, in a dense stand on a clayey soil and consists of plants that produce broadly winged seeds. 
of a totally different character (WESTHOFF 1947). The long stretch of flat beach north of the dunes, eastward of no. 22 marker pole, consists of a sandy soil which does not contain any clay or only a layer of a few centimetres thick in the topmost part. The beach plain is somewhat concave and in many low-lying places drainage is poor, so that rain water accumulates after heavy showers and some sea water is left behind after spring tides (the beach plane is not inundated at normal high water). After a period of prolonged drought with only a few inundations by exceptionally high tides, the top layer of the soil becomes desiccated. The moisture relations and the salt content fluctuate between extreme values, which is clearly reflected in the sparse vegetation cover (see photo 2). Inter- and intraspecific competition is negligible. These environmental conditions prevail in the more low-lying parts of the flat beach plane where $S$. media occurs. Comparable situations occur in the Westerkwelder and the Oosterkwelder in Schiermonnikoog, and at Kwade Hoek in Goeree (STERK 1968, 1969 a).

These data indicate that in corresponding types of habitat a corresponding range of variation is found. Transplantation experiments and rearings of plants from seed in the experimental garden have shown that the differences between the populations occurring in the above-mentioned habitats are chiefly attributable to a different genetic predisposition of these populations. There are, accordingly, good reasons to assume that the differentiation between the populations is an ecotypic one.

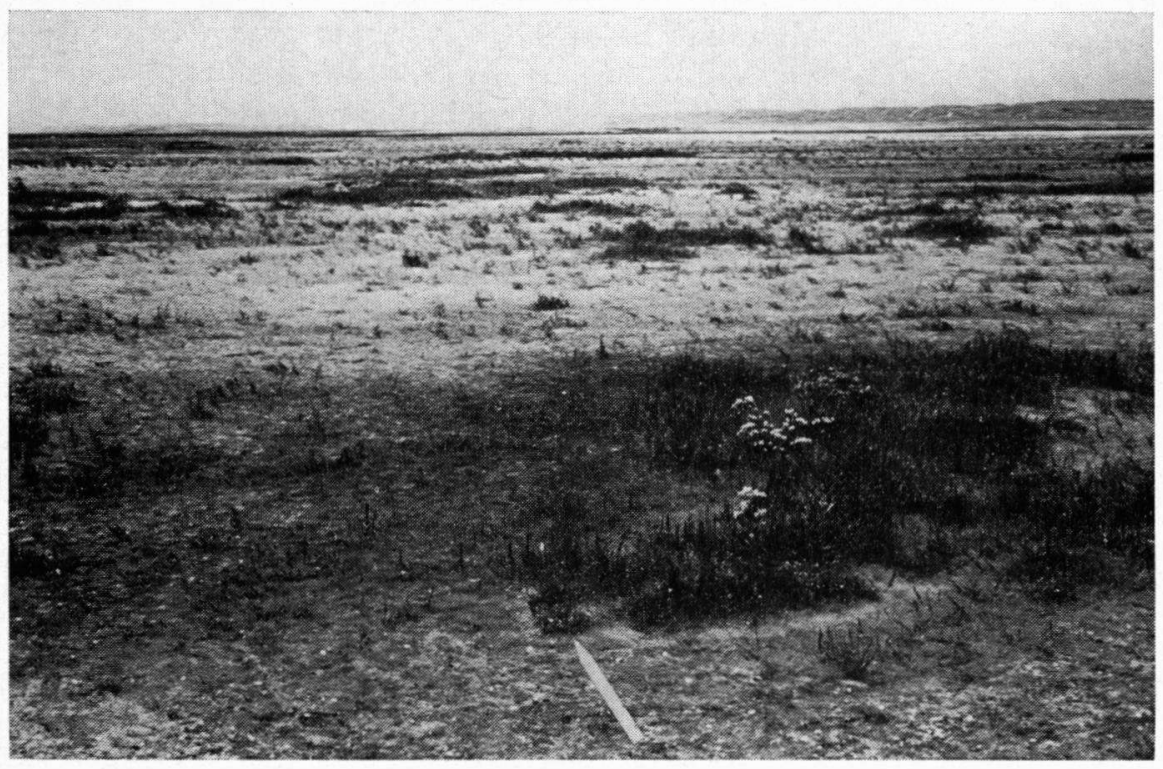

Photo 2. View of the habitat of S.media of "De Boschplaat" north of the dunes (Terschelling). The population grows on the bare sand plain and in the lower parts of the vegetation cover (see arrow); it contains about $30 \%$ of plants that produce exclusively unwinged seeds. 
In Terschelling, percentages of URW-capsules intermediate between the extreme percentages recorded at DE Grie $(0 \%)$ and at the Boschplaat near no. 26 marker pole $(30 \%)$ were noted in population samples from the saltings facing the Waddenzee, viz., $3 \%$ at De Groede, $11 \%$ near no. 23 marker pole, and $17 \%$ near no. 25 marker pole (see fig. 1). These mud flats of eastern Terschelling facing the Waddenzee occupy a more or less intermediate position in an ecological sense between the sites at De Grie and N. of no. 26 marker pole on the Boschplaat, and this may be the "explanation" of the intermediate percentages recorded in these localities.

It is rather striking that the percentage of URW-capsules consistently increases from De Groede eastwards on the Boschplaat, both north and south of the row of dunes, and also from south to north on the Boschplaat. This is manifestly a case of clinal variation. The underlying causes are complex and include environmental conditions, historical factors and the dispersal ecology of pollen and seeds in addition to the different, genetically determined ecological tolerances and preferences of BVW- and URW-plants. The clinal variation is not a simple E.-W. gradient of characters, however. A population occurring on the Oosterkwelder (Schiermonnikoog), between the second and third creek (between $\mathbf{R}$ and $\mathbf{S}$ beach marker poles), was studied in more detail. These gullies are oriented in an approximately N.-S.-direction at the Waddenzee end, where they are about $600 \mathrm{~m}$ apart and have low sandy banks. The bank of the second gully gradually slopes down towards the E. whilst the clay content in the soil gradually increases. Half-way between the two creeks the clay content is the highest to decrease again towards the $W$. bank of the third gully. The percentage of URW-capsules increases or decreases in a way which is strictly correlated with the changes in the relief of the landscape and the composition of the soil. On the sandy bank of the second creek the population sample contained $38 \%$ URW-capsules, which percentage gradually decreases to $20 \%$ in an eastward direction to about half way between the two gullies where the clay-content of the soil is highest, to increase again towards the W. bank of the third gully where it rises to $40 \%$. This is clearly indicative of a direct relation between the variation of the population and the relief (and hence the environmental conditions) of the habitat. It follows that the variation can change appreciably within short distances. A landscape with muddy flats intersected by gullies has both an intricate micro-relief and a varied soil composition, and consequently the pattern of variation shown by $S$. media in such an area is, likewise, complicated.

The area of the western part of the Oosterkwelder has a clayey soil and supports an almost closed stand of halophilous vegetation which is similar to that occurring in the sampling sites at De Groede in the island of Terschelling. The area is older than the corresponding part of De Groede and it is, therefore, remarkable that the percentage of URW-capsules is much higher $(12 \%)$ than that recorded at De Groede (3\%). The difference may be due to grazing. That intensive grazing is the apparent cause of a relatively high incidence of URWcapsules, can also be deduced from population samples from Ameland and from the Slufter (Texel). The population of the saltings near Hollum in Ameland 
BIOSYSTEMATIC STUDIES ON SPERGULARIA III.

shows the highest recorded percentage of URW-capsules, viz., $75 \%$. The soil consists of sand covered with a thin layer of clay. Grazing by sheep is very intensive, so that the vegetation cover is not completely closed and only a few centimetres high, Puccinellia maritima being the predominant species. The Juncetum gerardii which occurs on slightly more elevated soils, contains much Armeria maritima. The sample from the seaward sandy beach at the Slufter also contains a high percentage of URW-capsules, viz., $71 \%$. The soil is a humuscontaining, $6-8 \mathrm{~cm}$ thick layer of clayey sand on a sandy subsoil. The vegetation cover is not quite closed and, being intensively grazed by sheep, remains only a few centimetres high ; Puccinellia is most abundant here also. In the Puccinellietum scattered specimens of Armeria maritima occur. According to BEEFTINK (1965), Armeria maritima can establish itself in much-grazed Puccinellia vegetation.

The muddy flats constituting Nieuwlandsrijd in Ameland are of a considerable age (ISBARY 1936) and the soil is covered with a layer of clay $15-18 \mathrm{~cm}$ thick, so that in this site a low percentage of URW-capsules might be expected or none at all. Nevertheless the percentage is unduly high, viz., 35\%. Grazing by sheep is also very intensive here; the stand of vegetation is more or less closed and consists of a rather dense carpet of Puccinellia maritima interspersed with Armeria maritima. Apparently the effect of grazing alone is responsible for the high percentage of URW-capsules, but the thick, mineral-rich clay-layer presumably explains why this percentage is considerably lower than in the population occurring at Hollum. The fact that manifestly there is a connection between a high percentage of URW-capsules and grazing strongly suggests a causal relation. The possible selective effect of grazing was studied by rearing a progeny from seeds of URW-capsules collected at the Slufter. It is conceivable that damage to the plants caused by grazing is responsible for the development of a high percentage of URW-capsules on BVW- and NW-plants. However, the experiment showed that this is not the case; the high percentage of URWcapsules in the population sample is chiefly produced by URW-plants and not by BVW- or NW-plants; in other words, intensive grazing decides the genetic composition of the local population of $S$. media. The sites in the northern part of this country where the samples did not contain any URW-capsules, or only a low percentage of them, are not or hardly ever subjected to grazing (De Grie, De Groede, the Westerkwelder and the Balgzand). The other sites included in the present investigation have a soil consisting of sandy clay and they are more or less intensively subjected to grazing. Summarising, it can be concluded that the composition of a local population is the resultant of the effect of the prevailing environmental conditions and of the age and the history of the site on the one hand, and of the living conditions of URW-plants and BVW-plants on the other.

\subsubsection{Variation and environment in the south-west of the Netherlands}

For a detailed account of the ecological data relating to the populations studied in this area the reader is referred to STERK (1968).

In three sites situated in this part of the Dutch distributional area, viz., the 
Groene Strand (Oostvoorne), a dune valley at the Kwade Hoek (Goeree) and the Springersgors (Ouddorp), the percentage of URW-capsules is high $(28 \%, 21 \%$ and $10 \%$, respectively). These are all ungrazed flat sandy stretches of beach or a part thereof, have a sandy soil and support sparse stands of vegetation in which $S$. media is dominant. The ecological resemblance with habitats in the north western parts of the Netherlands where also high percentages of URWcapsules occur (such as the Boschplaat in Terschelling) seems to be responsible for the incidence of many plants with mainly exalate seeds.

All other population samples are characterised by the absence or low representation of URW-capsules, the highest percentage (viz., 3.4\%) having been found in the muddy flats at Heene (St.-Philipsland). In some sites the low degree of representation is somewhat unexpected. The so-called Middelplaten, islands in the Veerse Meer, originated by the damming up of this artificial lake, provide an example. In these Middelplaten an extensive young population of $S$. media occurs in sparse vegetation on a sandy soil, from which population no URWcapsules were recorded. This may be explained by the recent and rather sudden origin of the site and by vicinism, no URW-plants having been encountered in the populations of neighbouring sites such as the Spieringschor and the erstwhile muddy flats of the Westerlandpolder (see STERK 1969a). Barring a few sites, such as Springersgors and Kwade Hoek, the soils in the S.W. corner of the Netherlands contain more clay than those of the $N$. part of this country. The saltings have mostly already supported a closed stand of vegetation for a considerable lenght of time and grazing is usually not very intensive. It seems as if, on account of these environmental conditions, URW-plants could not establish themselves in the local populations.

A study of populations along macrogradients of, among other factors, salinity (from salty to fresh water), as found along the Western Scheldt and along the estuaries of Grevelingen, Krammer and Volkerak, did not reveal any correlation between variation and environment.

\subsubsection{Population density}

The population density was determined at six sites in Terschelling where population samples had already been taken. To this end, in each zone of the zonation shown by the stands of vegetation three narrow strips $(10 \mathrm{~cm}$ wide) were outlined at regular intervals lengthwise in the zone and in these narrow strips all plants were counted and dug up (for age determinations, see below). Flowering specimens and seedlings plus sterile juvenile plants were separately recorded. Table 2 shows the results, only the highest densities of the optimal vegetational zone being indicated.

It is evident that the density of the population is much higher in the sparse stands on the flat beaches $N$. of the dunes on the Boschplaat than in the closed stands S. of these dunes and at De Grie. The highest density was recorded at Boschplaat near no. 26 marker pole N. of the dunes. The high percentage of non-flowering plants among the samples of the beach plane near no. 23 and no. 26 marker poles is rather striking (compare fig. 1 ). 
BIOSYSTEMATIC STUDIES ON SPERGULARIA III.

Table 2. S.media. Densities of the investigated populations of Terschelling. Bos. = Boschplaat; N. = north of the dunes; $S$. = south of the dunes.

\begin{tabular}{llcc}
\hline Locality & \multicolumn{2}{c}{ Mean number of plants per $\mathrm{m}^{2}$} \\
\cline { 2 - 4 } & $\begin{array}{l}\text { Flowering } \\
\text { specimens }\end{array}$ & $\begin{array}{c}\text { Juvenile } \\
\text { plants }\end{array}$ & $\begin{array}{c}\text { Total area studied } \\
\left(\text { in } \mathrm{m}^{2}\right)\end{array}$ \\
\hline
\end{tabular}

\section{De Grie}

De Groede

Bos. p. 23, S.

Bos. p. 25, $\mathrm{S}$.

Bos. p. 23, N.

Bos. p. 26, N.

$\begin{array}{rr}9 & \\ 7 & \\ 6 & \\ 7 & 11 \\ 19 & 62 \\ 39 & 123\end{array}$

3,0

4,8

4,5

6,0

6,0

3,0

\subsubsection{The age pyramid of the populations}

$S$. media is a perennial species that behaves, depending on the habitat, as a hemicryptophyte or as a chamaephyte (according to Raunkiaer's system of life forms, see BRAUN-BLANQUET 1964). The overground parts die off almost completely by the beginning of the cold season, the basal stem parts and the root system persisting. The perennial parts of the stems are brown by being covered with a protective periderm layer. In spring new shoots emerge from the perennial stem bases. Age determinations based on external visible characteristics such as scars of died-off stem parts did not prove to be practicable. An anatomical investigation showed that the periderm may provide an indication of the age of the plant. From the examination of plants of known age reared from seed in the garden it could be established that the formation of a cork cambium under the epidermis commences towards the end of the first growing season when hibernation sets in. When the plant enters the second hibernating period another layer of cork is deposited which is separated from the first by a thin, lighter coloured layer formed during the growing season, and every additional cork layer is likewise separated from the older ones, thus providing an age gauge. However, when the stems get older, the layers are not so clearly distinguishable any more and the outer bark starts peeling off. An estimation of the total number of layers in the bark and a count of the visible layers indicate with a sufficient degree of accuracy that the oldest plants occurring at De Grie are 5 to 6 years old; the age of plants up to 3 years old can usually be determined with certainty. Table 3 shows the age groups recorded in four population samples from four different sites (compare fig. 1). Seedlings were not included in the numbers.

It appears that the populations from De Grie and De Groede mostly contain 2-3 years old and older plants, whereas the plants in the sample from Boschplaat mainly belong to the age groups $0-1$ year old and 1-2 years old.

The assembled data clearly show that differences in the habitat are reflected in differences in the stand density and in the average age of the various populations, which differences are obviously the result of adaptation to the prevailing environmental constellation. In the unstable milieu of the flat sandy beaches of 
Table 3. S. media. Age classes of 4 population samples from Terschelling from different habitats. N. = north of the dunes.

\begin{tabular}{lrrrc}
\hline \multirow{2}{*}{ Locality } & \multicolumn{5}{c}{$\begin{array}{c}\text { Percentages of plants } \\
\text { Age in years }\end{array}$} \\
\cline { 2 - 5 } & $0-1$ & $1-2$ & $2-3$ & 3 and older \\
\hline De Grie & 1 & 17 & 21 & 61 \\
De Groede & 2 & 14 & 29 & 55 \\
Boschplaat, p. 23, N. & 10 & 78 & 11 & 1 \\
Boschplaat, p. 26, N. & 51 & 39 & 10 & 0
\end{tabular}

the Boschplaat, in sparse vegetation, populations are found with a relatively high stand density and a predominance of the lower age groups. The shorter average life-span is clearly attributable to the extreme environmental conditions. In the more stable sites at De Grie and De Groede, with a dense vegetation cover, the stand density of $S$. media is much lower and the older age groups are much better represented.

\subsubsection{Discussion}

The present investigation revealed a correlation between variability and environment. At sites with a sparse plant cover on a sandy soil showing appreciable fluctuations in the conditions involved in e.g., the water and salt relations, the local populations contain a high percentage of plants producing exalate and relatively small seeds. A high representation of such plants is also found on clayey soils where the fluctuations in the abiotic environmental factors are not so pronounced, but intensive grazing takes place. Apparently frequent grazing has a similar effect as an extremely unstable abiotic environment. The highest percentages of plants with unwinged seeds were encountered in Puccinellia vegetations on silty sand in sites subjected to intensive grazing.

WeSTHOFF \& VAN LEEUWEN (1961) include the sites showing appreciable changes in their water-and salt relations in the course of time in the group of the "disturbed environments". Such environments always occur in places where milieus with opposed conditions meet, e.g., dry and wet ones, or salt- and freshwater ones. In the zones of contact the environmental factors may appreciably fluctuate in intensity. According to these authors, grazing and especially overgrazing is a disturbing factor. In other words, populations of S. media occurring in disturbed sites contain a high percentage of plants producing exalate seeds.

In clayey sites where the vegetation cover is dense and the fluctuations in the factors involved in the water- and salt relations vary within much narrower limits, the populations contain only a low percentage of plants with small exalate seeds or none at all. It was shown by rearing plants in the garden and by studying progenies that the characteristics of the seed classes "small and exalate" and "large and winged" are essentially of a hereditary nature. Populations differing in this respect must, accordingly, differ in genetic composition. This immediately raises the question whether the variation is an ecotypic one, i.e., 
if the hereditary variation is of an adaptive nature. The mere fact that in the populations of disturbed habitats consistently many plants with small unwinged seeds occur indicates that the probability of this being a chance coincidence is very remote; in other words, the plants with smaller, unwinged seeds are most probably better adapted to a disturbed habitat. The ecotypic differentiation between the different populations of $S$. media are presumably attributable to a process of natural selection. The process of selection can be visualised as either of the two opposite alternatives:

1. the selection process favours plants with large BVW-seeds, or

2. the selection process favours plants with small URW-seeds.

The first possibility would ultimately result in populations consisting exclusively of plants with bvw-seeds; such populations are quite common in this country, whereas the expected result of the other selection process, viz., populations of exclusively urw-seeds producing plants, has not been encountered.

However, from descriptions given by MONNIER $(1953,1962)$, and, indirectly, from those of MonNiER \& RATTER in Flora Europaea Pt. I and of RATTER (1959) it can be deduced that elsewhere in Europe populations of $S$. media with exclusively exalate seeds do occur. This is corroborated by personal observations of the present author made in the beach plane of Nørreland near Lakolk in the Danish North Sea Island of Rømø where a mass-collected sample of capsules of the local population proved to contain $99 \%$ of URW-capsules. In such cases the alternative direction of selection apparently attains its ultimate stage. In the populations found in the Netherlands selection pressure seems to be insufficient to achieve this here.

In the case of $S$. media an ecocline can be construed in which the extremes are populations containing only BVW-plants and populations containing only URW-plants. The cline is an abstraction, however, which, in N.W. Europe, is perhaps more or less clearly materialised in the Danish island of Rømø, where the population of the broad sandy beach of the North Sea, which consists of URW-plants as we have seen, gradually changed along the north side of the island into the stand of the clayey saltings consisting of BVW-plants. Transitions from sandy beaches covered with Puccinellia vegetation to clayey muddy flats also supporting stands of Puccinellia vegetation are extremely rare and, accordingly, the corresponding ecocline must be rare. In all situations where a form of clinal variation is found, incidentally, the general rule applies that this variation is not strictly a progressive change in one direction. The variation is always associated with ecological gradients (micro-gradients) in the landscape which are mainly brought about by the micro-relief. The surface relief being very complicated in estuarial regions with muddy flats, the pattern of variation is, likewise, an intricate one. In the Netherlands the populations mostly occur in more or less isolated sites, so that the differences between the variation patterns within these populations are usually more or less abrupt.

In the population complex in the island of Terschelling there is a certain correlation between the various age groups present, the population density, and the genetically determined variability in the degree of development of the seed wing 
and in seed size on the one hand, and the environment on the other. According as the plant cover of the site where $S$. media occurs becomes denser and the environmental conditions thus become less extreme and more stable (compare photo 2 with photo 1 ), the individual specimens attain a higher mean age and the genetic variability in seed wing development and seed size decreases. This phenomenon is not of incidental occurrence, as can be deduced from the disquisitions on the subject by MARGalef (1963): when populations of a given species occur in ecosystems of different structural complexity, the demographic structure is, generally speaking, also diversified in such a way that in the more complex ecosystems the organisms upon the average attain a greater age. According to Margalef, more complex systems contain more stenoecious forms than less complex ones. Apparently the number of ecological niches increases in ecosystems with a more highly developed structure, but these niches are more narrowly delimited and the environmental conditions do not have such a wide amplitude. The genetic variability of the populations tends to decrease when the niches are more clearly delimited. It is of importance in this connection that an increasing complexity is concomitant with an increase in stability (VAN LEEUWEN 1966). Stability results in a constant direction of the selection pressure and this leads to a diminishing genetic variability. On the other hand, if an environment progressively turns extreme and unstable the genetic variation of $S$. media also decreases: apparently the conditions are of such an extreme nature that only a small number of biotypes can maintain themselves.

Between the extremes of fairly stable and not very changeable habitats and the very unstable and harsh milieus, there must be some environments in which the variability of the seed size and the seed wing development is the greatest. In such mesic habitats the winged and the exalate forms, which do not occur in mixed populations in the relatively stable and in very unstable environments, occur in cohabitation. In such situations Gause's rule (see DAvIS \& HEYwOOD 1963) clearly does not apply. The population density in stands of $S$. media falls off according as the vegetation cover assumes a more "closed" character, which decrease is apparently to be ascribed to an increasing competition, the competitive capacities of $S$. media in respect of the other species present determining the population density.

Important are the questions of the action of the process of selection taking place in a population complex of $S$. media, and in which part of the life cycle it is operative and in what way. For a discussion of these problems the results of older studies can be taken as starting point:

a. By studying 240 species from different habitats in Britain SALISBURY (1942) could show that upon the whole seed weight and seed size increase in the sequence of: plants from "open" sites, from dense stands of herbaceous vegetation, from scrub vegetation, and from forests. According to this worker, the larger seedlings from the larger seeds have better chances of survival in dense stands than the small seedlings from smaller seeds. The better chances of survival of the seedlings from larger seeds in the more advanced successional stages of vegetation development are supposed to be the direct result of the presence 
BIOSYSTEMATIC STUDIES ON SPERGULARIA III.

of a larger embryo and the greater amount of storage products at its disposal. In this context a study by BLACK (1957) is of special significance. He found that in three races of Trifolium subterraneum L. the dry weight of juvenile specimens and the surface area of the leaves is linearly proportional to the seed weight. The differences between the races under discussion are not explicable by means of different growth rates. The larger the seeds, the larger the juvenile plants. Not only the larger embryo and the greater supply of stored nutrients are important in this connection, but also the larger cotyledons of the seedling (with a larger assimilatory surface area) after the storage products have been completely used up. According to Black, larger cotyledons have a considerable selective value in environments where competition is fierce. Following Salisbury's train of thought, one can thus conclude that the absence of plants with small exalate seeds in a dense plant cover is the direct result of the better chances of survival of seedlings developing out of the larger type of seeds, chiefly on account of the amount of light and of their competitive capacities.

b. Investigations by HARPER \& BENTON (1960) have shown that the water relations and water economics of larger and smaller seeds are different owing to a different ratio between the surface area of the testa in contact with the soil surface and the surface area of the testa in contact with the atmosphere. Larger seeds tend to suffer from desiccation sooner than comparable smaller ones, so that plants with larger seeds prefer dense stands of vegetation where the protection is better, and plant with smaller seeds prefer sparser vegetation. According to this train of thought the selection could be operative during seed germination, the water relations in dense stands being more favourable for the germination of larger winged seeds of $S$. media than for the development of smaller exalate seeds, and the reverse being the case in sparse vegetation. This might be the explanation of the predominance of plants with small, exalate seeds in "open" sites and the absence of these plants in dense stands of vegetation.

c. The process of selection may also be operative in an altogether different phase of the life cycle. As I previously demonstrated (STERK 1969a) the more distally produced capsules of the inflorescence contain considerably more exalate (and hence: smaller) seeds than the proximally produced fruits, and plants grown on a soil poor in nutrients produce relatively more small, exalate seeds than comparable plants grown on a rich soil. It seems as if in unfavourable developmental conditions a relatively greater number of unwinged seeds are being produced. It is conceivable that after the occurrence of mutations causing the formation of smaller and less broadly winged seeds the mutated individuals, on account of a more economical utilisation of their assimilates and of their biochemical synthesising potential, have a better chance of survival in less favourable circumstances than plants producing large, winged seeds. This would provide another example of the parallel development of a habitat-induced phenotypic modification and a genetic adaptation, a phenomenon already mentioned in the literature before. These are only some possible causes of selection pressure, which may possibly even act in combination. Further research is highly desirable. 
All previous considerations are based on the primary assumption that selective processes act directly upon characters associated with the size and the morphology of the seed. Studies of the genetic structure of ecotypes have revealed that certain morphological features are correlated with physiological characters of a highly adaptive nature by "interlocking heredity" (CLAUSEN 1967). It is feasible that in populations of $S$. media the selection process acts primarily on a character or a complex of characters of, e.g., a physiological nature genetically linked with seed size, and that the seed size as such has no primary adaptive significance.

For the rest, a correlation between variation and environment has not been observed in all populations studied in the Netherlands. The cases where, contrary to expectation, no such correlation was demonstrable, could be satisfactorily explained by the very low degree of accessibility and the recent origin of the site, combined with the absence of URW-plants in the neighbouring populations.

As was pointed out already, references in the taxonomic literature clearly indicate that forms of $S$. media with exalate seeds occur along the whole W.-European coast. My personal investigations suggest that in the Danish North Sea Islands (Skallingen, Rømø) the same correlation between seed morphology and local environment obtains as in the Dutch region, and most probably this applies to the whole Dutch-German-Danish coastal area in between. No clear indications can be gleaned from the literature concerning the presence of the correlation in question along the remainder of the W.-European coastal zones. A personal investigation of an extensive population of $S$. media occurring on the flat sandy beaches of the bay near La Palmyre (in the area of Royan, Charente Maritime, France) revealed the complete absence of plants with exalate seeds. From this case it may be concluded that also elsewhere in Europe the correlation under discussion is not always found in sites where it might be expected to occur. According to Monnier (in litt.) plants with exalate seeds occur near La Rochelle (Charente Maritime, France) north of Royan. Probably historical factors are important in connection with the distribution of plants with exalate seeds along the West-European coast.

\subsection{S. marina}

For a more extensive survey of the ecological data relating to the populations studied the reader is referred to a previous paper (STERK 1968). S. marina is a differentiating species of the alliance Puccinellio maritimae-Spergularion salinae BEEFTINK 1965 (differentiating against the Puccinellion maritimae and the Armerion maritimae). The alliance includes three associations, viz.,

1. the Puccinellietum distantis FEEKES 1943,

2. the Puccinellietum fasciculatae BEEFTINK 1965, and

3. the Puccinellietum retroflexae (AlmQUIST 1929) BEEFTINK 1965, which three associations exhibit a high degree of mutual ecological relationship. The Puccinellietum distantis occurs both inside and to the seaward of the dikes, whereas the other two are chiefly encountered on the landward side of the dikes. 
The Puccinellietum retroflexae is of rare occurrence in the Netherlands and the Puccinellietum fasciculatae is absent in the northern part of this country (WESTHOFF 1947; BEEFTINK 1965). S. marina is represented in all three communities with a high degree of presence (90\% to $100 \%$ ). Beeftink proposed the recognition, within the alliance, of an additional community or sociation, viz., a Spergularietum salinae (or Spergularia salina sociation) for those stands with dominance of $S$. marina in which species of Puccinellia are absent or very scattered. Communities of this kind are repeatedly encountered in suitable habitats in the Netherlands, for instance in more low-lying parts such as pools which have fallen dry amidst stands of Puccinellion- or Armerion communities. In such pools the water level fluctuates considerably; in the summer they fall more or less completely dry depending on the amount of seasonal precipitation, but in the autumn, the cold season and the spring they hold water. In such places $S$. marina is dominant and usually completely so. In such habitats the environment is clearly different from that in the three above-mentioned associations which is apparent from the absence of the species of Puccinellia. S. marina clearly possesses a much wider ecological amplitude than these three grasses and the respective amplitudes do not all coincide. The recordings of stands are not sufficiently numerous to permit a conclusion concerning the phytosociological problem: is it to be called a Spergularietum salinae or a Spergularia salina-sociation? The population with appreciable numbers of BVW-plants only occurs at De Grie (Terschelling) in a faintly undulating transitional area between the dune landscape and the older saltings (see fig. 1 page 564 and photo 3). S. marina occurs in this locality in pools or alongside pools that are inundated from the autumn till the springtime and periodically or completely fall dry during the summer. When dry, they support vegetation of predominantly $S$. marina intermingled with a few scattered specimens of Suaeda maritima, Atriplex hastata and Agrostis stolonifera. In the locality of De Grie the meadowland surrounding the pools contains chiefly species of the AgropyroRumicion Nordhagen, intermingled with some elements of more halophilous vegetation (viz., of the Armerion maritimae). Communities of the AgropyroRumicion are characteristic of more or less unstable contact zones between contrasting environmental situations, in the case under discussion between brackish and fresh water zones. The life cycle of $S$. marina is fitted into this unstable environment in such a way that the plants complete the whole cycle within the relatively short period during which the pools stay dry: the plants are nearly always of modest stature and set seed relatively fast. Plants of $S$. marina also tend to remain small in all localities where intraspecific competition is strong. It is striking that in some desiccated pools also groups of plants occur entirely consisting of URW-plants. In the present state of the investigation it is difficult to provide a satisfactory explanation of the very limited distribution of BVW-plants of S. marina. Conceivably the genotype "winged seeds" has arisen by mutation only recently, so that the limited distributional area is to be ascribed to the recent origin. Alternatively, the distributional area is so small in size for the simple reason that habitats suitable for the form with winged seeds 


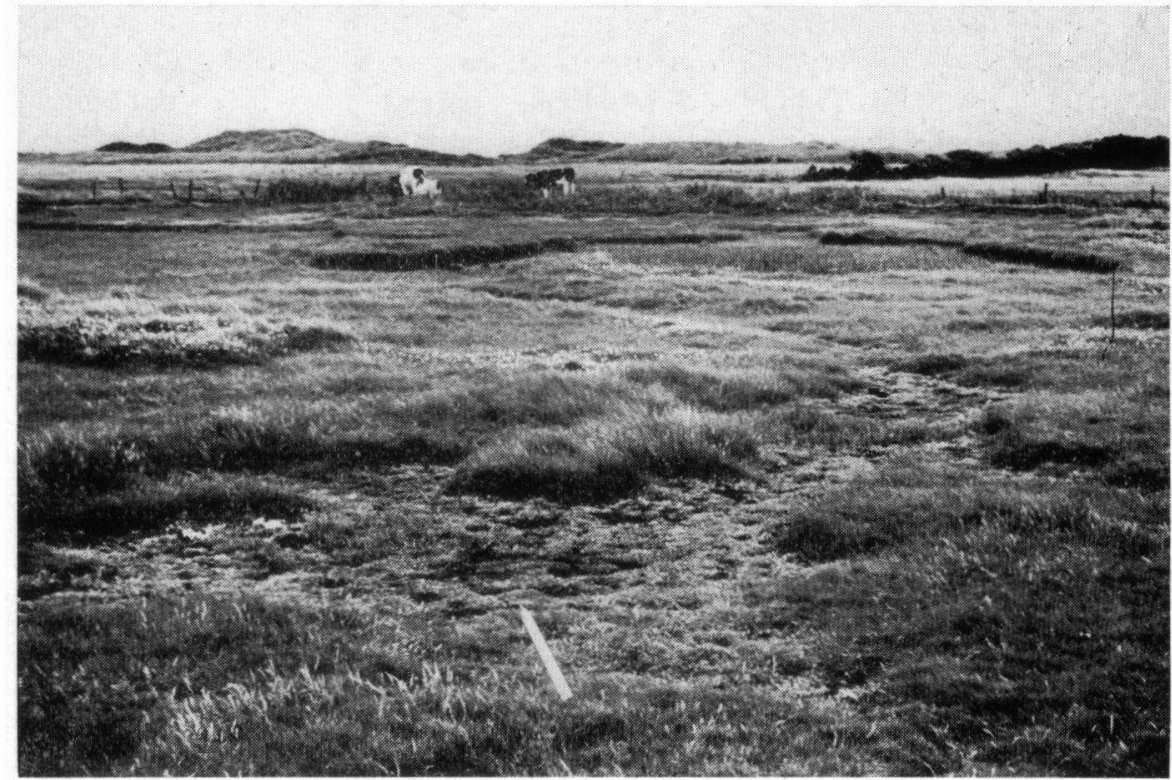

Photo 3. The habitat of S.marina of "De Grie" (Terschelling) situated between the duckponds. The population contains about $70 \%$ of plants that produce broadly winged seeds.

are so rare in this country. Transitional localities, as found at De Grie, are also scarce. Somewhat comparable sites are found in Ameland (Nieuwlandsrijd) and in Schiermonnikoog (along the southern edge of the Kobbeduinen), but only URW-plants occur there, however. A third possibility is that the form with winged seeds arises repeatedly in nature by recombination of genetic factors upon the rare occasions that cross-fertilisation takes place in this predominantly autogamous species, but can not maintain itself in most of the environments where it appears, either because the abiotic milieu does not provide sufficient chances of survival or because it is soon ousted out by the better adapted unwinged type. The considerable contribution of chance factors towards the establishment of gene frequencies in small populations was shown by Sewal Wright. That this may also be of importance in populations of $S$. marina was observed during visits to the same sites in consecutive years in the transitional zone between dunes and muddy flats. In one instance the abundant rain fall had prevented the development of a stand in a site where the year before a considerable population had been found growing. After a thorough search only a single minute specimen was discovered. In this type of habitat, but conceivably also in other ones, appreciable fluctuations in population density and population size may take place which could lead to the disappearance of genes or alleles through genetic drift. That chance establishments of a few plants from diaspores in not easily accessible places may be the cause of a certain pattern of variation 
(the so-called "founder principle") has repeatedly been noted. For example, on the mole of Yerseke and in some other localities, small populations occur in which all flowers are of exactly the same colour and the limits of variation of the number of stamens per flower are narrow. Generally speaking, the conclusion may be drawn that, in the Netherlands, the variation pattern of $S$. marina is often tangibly influenced by chance factors operative in small populations in isolated localities and favoured by the autogamous process of reproduction.

\section{ACKNOWLEDGEMENTS}

This paper, the third of a series of four, represents parts of the thesis for a Dr. Phil. degree prepared under the guidance of Prof. J. Lanjouw, State University, Utrecht. The author is much indebted to Prof. A. D. J. Meeuse, Hugo de Vries-Laboratorium, University of Amsterdam, who translated the Dutch text.

\section{REFERENCES}

BEEFTINK, W. G. (1965): De zoutvegetatie van $Z W$-Nederland beschouwd in Europees verband. Thesis. Wageningen.

BLACK, J. N. (1957): The early vegetative growth of three strains of subterranean clover (Trifolium subterraneum L.) in relation to size of seed. Aust.J. Agric. Res. 8: 1-14.

Braun-Blanquet, J. (1964): Pfanzensoziologie. 3e Auft. Wien.

Clausen, J. (1967): Biosystematic consequences of ecotypic and chromosomal differentiation. Taxon 16 (4): 271-279.

Davis, P. H. \& V. H. HeYwood (1963): Principles of Angiosperm Taxonomy. London.

ELLENBERG. H. (1956): Aufgaben und Methoden der Vegetationskunde. Stuttgart.

HARPER, J. L. \& R. A. Benton (1966): The behaviour of seeds in soil II. The germination of seeds on the surface of a water supplying substrate. J. Ecol. 54 (1): 151-166.

Heukels, H. \& S. J. van Ooststroom (1962) Flora van Nederland ed.15: 206. Groningen.

Isbary, G. (1936): Das Inselgebiet von Ameland bis Rottumeroog. Arch. Deutsch. Seewarte $56,3$.

LeeuWEN, C. G. van (1966): A relation theoretical approach to pattern and process in vegetation. Wentia 15: 25-46.

Margalef, R. (1963): On certain unifying principles in ecology. Am. Nat. XCVII, 897: 357-374.

MonNiER, P. (1953): Sur quelques spergulaires du Maroc appartenant au groupe de Spergula marginata (DC). Murb. Rec. trav. lab. Bot. Geol. Zool. série Bot. 6: 77-88. Montpellier.

- (1962): Biogéographie et micro-évolution chez Spergularia marginata Kittel dans le bassin méditerranéen occidental, Afrique du Nord notamment. Rec. Cyt. Biol. Vég. 25 (3-4): 325-335.

RATTER, J. A. (1959): A cytogenetic study in Spergularia. Diss. Liverpool.

SALISBURY, E. J. (1942): The reproductive capacity of plants. London.

STERK, A. A. (1968): Een studie van de variabiliteit van Spergularia media en Spergularia marina van Nederland. Thesis. Utrecht. 156 pp.

- (1969a): Biosystematic studies of Spergularia media and S.marina in the Netherlands I. The morphological variability of S.media. Acta Bot. Neerl. 18(2): 325-338.

Tutin, T. G., V. H. Heywood, N. A. Burgess, D. H. Valentine, S. M. Walters, D. A. WeBB (1964): Flora Europaea 1: 155. Cambridge.

WESTHOFF, V. (1947): The vegetation of dunes and saltmarshes on the Dutch islands of Terschelling, Vlieland and Texel, Thesis. Utrecht.

WesthofF, V. \& C. G. VAN LeEUWEN (1961): Ökologische und systematische Beziehungen zwischen natürlicher und anthropogener Vegetation. Ber. Int. Symp. Stolzenau/Weser: 156-172.

WHITTAKER, R. H. (1962): Classification of natural communities. Bot. Rev. 28 (1): 1-239. 